\title{
Criatividade industrial
}

\author{
As indústrias culturais vêm se destacando por seu potencial eco- \\ nômico e social. Ao combinar análises teóricas e informações \\ de mercado, duas obras contribuem para dar visibilidade a esse \\ novo setor e para a discussão sobre como melhor desenvolvêlo.
}

por Maria Alice Gouveia FGV-EAESP

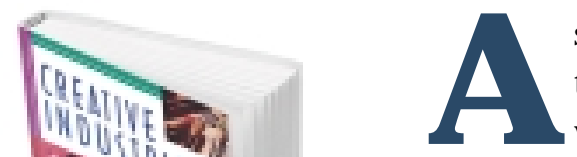

$\mathbf{A}$ s indústrias culturais vêm, em todo o mundo, recebendo cada vez mais atenção por parte de governos e empreendedores privados. 0 motivo é a percepção de que o setor tem forte potencial econômico, além de sua importância como meio de reflexão sobre a sociedade e a cultura. No entanto, apesar do interesse, ainda representam um setor da economia pouco explorado e pouco estudado.

Creative Industries Richard Craves Harvard University Press, Cambridge, 2001

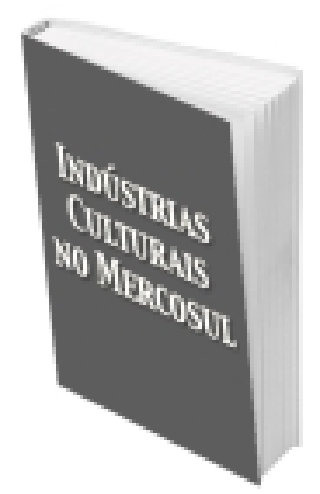

Indústrias Culturais no Mercosul

Gabriel 0. Alvarez (Org.) Instituto Brasileiro de Relações Internacionais, Brasília, 2003
$\mathrm{N}$ a verdade, as indústrias culturais constituem um fenômeno relativamente antigo. Estima-se que elas tenham se instalado na América Latina a partir do final do século XIX e começo do sécuIo $X X$, baseadas, quase exclusivamente, na iniciativa privada. Foi nesse período que surgiram as indústrias do livro, os jornais e revistas, o rádio, o cinema e o disco. 0 setor público brasileiro nunca teve presença representativa na produção cultural em escala industrial. A exceção, recente, é constituída pelas iniciativas de estímulo à produção cinematográfica.

Esse quadro começou a se alterar com o desenvolvimento da TV e com o processo de internacionalização da economia e integração dos mercados, ocorrido a partir dos anos 1990. A partir daí, as indústrias culturais passaram a despertar a preocupação de áreas governamentais. $\mathrm{Na}$ base dessa preocupação estava a idéia de que os países menos desenvolvidos tornar-seiam pontos-de-venda para os produtos criados e elaborados nos países centrais, especialmente nos Estados Unidos. Caberia ao governo assumir maior controle da situação para impedir uma possível invasão cultural externa. Deve-se notar que a preocupação era voltada para o conteúdo dessas indústrias, e não para suas possíveis vantagens econômicas.

É nesse contexto que as duas leituras aqui sugeridas se tornam relevantes. 0 primeiro livro, Indústrias culturais no M ercosul, é uma compilação de dados e informações que visa identificar o estado atual e as tendências mais recentes do desenvolvimento dessas indústrias nos países do M ercosul. 0 segundo, Creative industries, contém uma rigorosa análise dessas indústrias, a partir de um prisma econômico, envolvendo uma discussão do processo de cria- 
ção e consumo de produtos culturais "simples", tais como obras de arte, livros e "complexos" tais como filmes e grandes espetáculos.

Indústrias culturais no $M$ ercosul é 0 resultado de várias reuniões técnicas entre especialistas da região platina. A presenta capítulos dedicados a Argentina, Brasil, Paraguai, Chile, Bolívia e comunidade andina. Reúne informações inéditas sobre o setor nesses países, tais como o PIB das indústrias culturais brasileiras - que, em 2000, já havia alcançado os US\$ 12 bilhões -; índices per capta de livros e revistas lançados; percentual de lares com apareIhos de TV e vídeo; índice de assiduidade às sal as de cinema; e dados sobre faturamento bruto do setor.

0 livro discute também as condições de comércio, intercâmbio e circulação de produtos culturais nos países da região. As condições de integração dos mercados, principalmente do mercado de mão-de-obra regional e as tendências do crescimento do consumo de produtos culturais industrializados, completam o quadro de análise.

Creative industries, por sua vez, apresenta as características próprias do sistema de produção e circulação de bens culturais, os quais fazem da economia da cultura uma área especial e diferenciada. Entre as características analisadas, incluem-se: a imprevisibilidade do sucesso do produto cultural; a relação dos produtores com seus produtos - que não é baseada apenas em perspectivas de ganhos financeiros -; as restrições quanto à disponibilidade de mão-de-obra qualificada; as limitações à existência de concorrência direta; a pressão do tempo sobre todos os elos da cadeia produtiva e sobre resultados; e, finalmente, a longa vida dos produtos criativos, cujo consumo se prolonga mesmo depois de vários anos após o desaparecimento de seu autor, por meio dos direitos autorais.

Recomendamos a leitura desses dois livros pela combinação que representam. Enquanto o primeiro oferece informações sobre a realidade das indústrias culturais de nossa região, o segundo apresenta ao leitor referências e modelos conceituais de análise. Ambos estão escritos em linguagem clara e acessível, e serão de grande valia para a compreensão desse setor de crescente importância estratégica e cultural.

Maria Alice Gouveia

Mestre em Artes Plásticas pela UNESP

E-mail: rsantos@fgvsp.br 